DOI:10.22337/2587-9618-2020-16-1-98-105

\title{
A PROBABLISTIC APPROACH TO EVALUATION OF THE ULTIMATE LOAD ON FLEXURAL RC ELEMENT ON CRACK LENGTH
}

\author{
Sergey A. Solovyev \\ Vologda State University, Vologda, Russia
}

\begin{abstract}
The fracture mechanics of concrete and reinforced concrete is a promising direction in the development of methods for reinforced concrete structural elements design and inspection. At the same time, probabilistic methods of design and behavior analysis of structural elements are of particular interest. The article describes a probabilistic approach to load-bearing capacity and reliability analysis of flexural reinforced concrete elements based on the crack length criterion. The functional relationship between the critical stress intensity coefficient of concrete and the design compressive strength of concrete is given. The article presents a method for the reliability analysis of flexural reinforced concrete elements at the operational stage with limited statistical data about the critical stress intensity coefficient of concrete. The ultimate value of the failure probability (or reliability index) should be set for each object individually based on the value of the acceptable risk.
\end{abstract}

Key words: reliability theory, fracture mechanics, crack length, reinforced concrete beam, reinforced concrete slab, safety

\section{ВЕРОЯТНОСТНЫЙ ПОДХОД К ОПРЕДЕЛЕНИЮ ДОПУСТИМОЙ НАГРУЗКИ НА ИЗГИБАЕМЫЙ ЖЕЛЕЗОБЕТОННЫЙ ЭЛЕМЕНТ ПО КРИТЕРИЮ ДЛИНЫ ТРЕЩИНЫ}

\author{
С.А. Соловьев \\ Вологодский государственный университет, г. Вологда, РОССИЯ
}

\begin{abstract}
Аннотация: Механика разрушения бетона и железобетона является перспективным направлением в развитии методов расчета железобетонных элементов конструкций. В то же время, особый интерес представляют вероятностные методы расчета и анализа работы несущих элементов строительных конструкций. В работе рассмотрен вероятностный подход к расчету несущей способности и надежности изгибаемых железобетонных элементов по критерию длины трещины. Приведена функциональная зависимость между критическим коэффициентом интенсивности напряжений бетона и расчетным сопротивлением бетона. В статье представлен метод расчета надежности изгибаемого железобетонного элемента на стадии эксплуатации при ограниченной статистической информации о критическом коэффициенте интенсивности напряжений бетона. Предельное значение вероятности безотказной работы (или индекса надежности) следует устанавливать для каждого объекта индивидуально, исходя из значения допустимого риска.
\end{abstract}

Ключевые слова: теория надежности, механика разрушения, длина трещины, железобетонная балка, железобетонная плита, безопасность

\section{INTRODUCTION}

Reinforced concrete flexural elements (beams and slabs) are common parts of different structures. The safety of a whole structure depends from the reinforced concrete beams/slabs safety and reliability. By Eurocode 0 "Basis of structural design", the reliability the ability of a structure or a structural member to fulfill the specified requirements, including 
the design working life, for which it has been designed. Reliability covers safety, serviceability and durability of a structure and is usually expressed in probabilistic terms. The measure of reliability is the failure probability or safety probability.

As noted in [1], for an adequate description of structural behavior, probabilistic methods must be resorted to. Properly speaking, an element of probability is embodied even in the deterministic approach, which claims to "simplify" the structure by eliminating all aspects of uncertainty. In practice structural reliability (or structural probabilistic design) increasingly is being applied, particularly for situations where quantitative, data-based risk assessment of non-elementary structural or other systems required [2].

Reinforced concrete (RC) flexural elements beams and slabs are common structural elements in many buildings. Safety assessment of these elements is an important task. K.A.Piradov and N.V. Savickij [3] note that there is no theoretically justified approach for the design of reinforced concrete structural elements with cracks at the moment (reinforced concrete elements, especially without reinforcement prestressing, usually contain cracks at design loads), and current design method (safety factors method or limit state method from 1955) is based on a number of theoretically unsubstantiated empirical coefficients. Fracture mechanics $[4,5,6]$ can be successfully applied for design of reinforced concrete elements with cracks. The relationship between fracture mechanics and reliability theory can be a powerful tool for evaluating the structural safety of reinforced concrete elements.

\section{METHODS}

There are different approaches to limiting the normal crack length in reinforced concrete beams. Some approaches limit the crack length to a percentage of the element's cross-section height. The research [7] notes that the crack length must not exceed $0.3 h_{0}$, where $h_{0}-$ distance from extreme compression fiber to centroid of longitudinal tension reinforcement. Gvozdev A.A. [8] proposed to limit crack length by value $0.5 h$, where $h$ - beam cross-section height. The research [9] offers next critical values: $0,7 \mathrm{~h}$, if there is a crack in the middle of the beam span; $0,65 h$, if in a third of the span and $0,3 h$ if at the support points (shear area).

More objective provisions for limiting the crack length can be obtained from the fracture mechanics equations for concrete and reinforced concrete. Thus, the following dependence is proposed in [10]:

$$
l_{c r c}=\frac{M^{2} \cdot Y_{1}^{2}\left(a_{1}\right) \cdot([2 \pi-1] / 2 \pi)}{\left(K_{I C}^{b}+K_{I C}^{s}\right)^{2} b^{2} h},
$$

where $M$ - bending moment in the beam crosssection; $K_{I C}^{b}-$ critical stress intensity coefficient of concrete; $K_{I C}^{s}-$ critical stress intensity coefficient which characterizes the restraining effect of reinforcement on crack growth; $b$ - width of the beam cross-section; $h-$ height of the beam cross-section.

Function $Y_{1}\left(a_{1}\right)$ have the form

$$
Y_{1}\left(a_{1}\right)=\sqrt{\pi}-a_{1}-1,
$$

where $a_{1}=a / h ; a$ - distance from extreme tensile fiber to centroid of longitudinal tension reinforcement.

The parameter $K_{I C}^{S}$ have the form (for normal crack):

$$
K_{I C}^{s}=\frac{60 A_{s}}{b \sqrt{\pi \cdot a}}\left\lfloor\frac{0,93}{\sqrt{1-a_{1}}}+\frac{1}{\sqrt{1-a_{1}^{2}}}-0,93\right\rfloor
$$

If we limit the crack length to a critical value $l_{\text {crc ult }}$, then the following equation can be derived from equation (1) to evaluate the 
bearing capacity (ultimate bending moment $M_{u l t}$ ) of beam:

$$
M_{u l t}=\sqrt{\frac{l_{c r c, u l t} \cdot\left(K_{I C}^{b}+K_{I C}^{s}\right)^{2} b^{2} h}{\left(\sqrt{\pi}-\frac{a}{h}-1\right) \cdot\left(\frac{2 \pi-1}{2 \pi}\right)}} .
$$

In accordance with the recommendations [10] and SP 63.13330.2018 "Concrete and reinforced concrete structures", the relationship between the critical stress intensity coefficient in concrete and the design compressive strength of concrete can be represented graphically (see Figure 1).

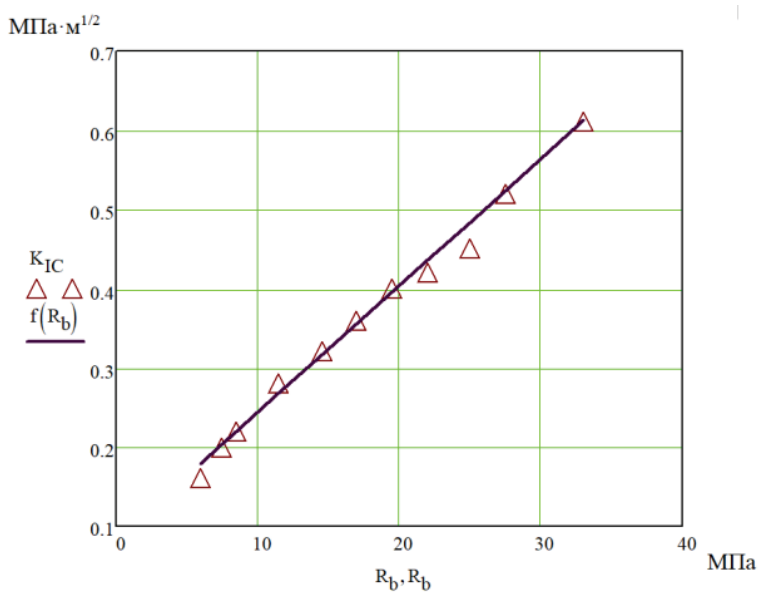

Figure 1. Functional relationship between

the critical stress intensity coefficient in concrete and the design compressive strength of concrete.

This dependence also can be approximated as a linear function (in $\mathrm{MPa}$ ):

$$
K_{I C}^{b}\left(R_{b}\right)=0.084+0.016 \cdot R_{b} .
$$

Thus, having the functional relationship between the critical stress intensity coefficient in concrete and the design compressive strength of concrete it is possible to calculate critical stress intensity coefficient for the existing concrete by determining the compressive strength (for example, by non-destructive testing).

The problem of assigning the ultimate crack length for a reinforced concrete beam also can be solved. If we take

$$
M_{u l t}=R_{b} b x\left(h_{0}-0,5 x\right),
$$

then the ultimate crack length can be expressed as:

$$
\begin{aligned}
& l_{c r c, u l t}=\frac{\left[R_{b} b x\left(h_{0}-0.5 x\right)\right]^{2} \cdot\left[\sqrt{\pi}-a_{1}-1\right]^{2}}{\left(K_{I C}^{b}+K_{I C}^{s}\right)^{2} b^{2} h} \times \\
& \times([2 \pi-1] / 2 \pi)
\end{aligned}
$$

where

$$
x=\frac{R_{s} A_{s}}{R_{b} b},
$$

$R_{b}$ and $R_{s}$ - compressive strength of concrete and tensile strength of reinforcement; $A_{s}$ - area of nonprestressed longitudinal tension reinforcement.

\section{RESULTS AND DISCUSSION}

Example 1. The reinforced concrete beam (without prestressed reinforcement) with crosssection dimensions $h=500 \mathrm{~mm}$ and $b=250 \mathrm{~mm}$. Reinforcement: 5 bars with $\phi 12 \mathrm{~mm}$ $\left(A_{s}=1.231 \cdot 10^{-4} \mathrm{~m}^{2}\right.$ ), with distance from extreme tensile fiber to centroid of longitudinal tension reinforcement $a=40 \mathrm{~mm}$. Then by eq. (2): $K_{I C}^{s}=0,543 \mathrm{MPa} \cdot \mathrm{m}^{2}$. Beam span $l=6 \mathrm{~m}$. If beam simply supported, then:

$$
M=\frac{q l^{2}}{8} .
$$

Figure 2 shows graph of the dependence of the ultimate load $q$ on the required height $h$ of cross section (with $K_{I C}^{b}=0,32 \mathrm{MPa} \cdot \mathrm{m}^{2}$ ) for different approaches to limiting the crack length in 
concrete $-0.3 h, 0.5 h$ and $0.7 h$ according to example 1 data.

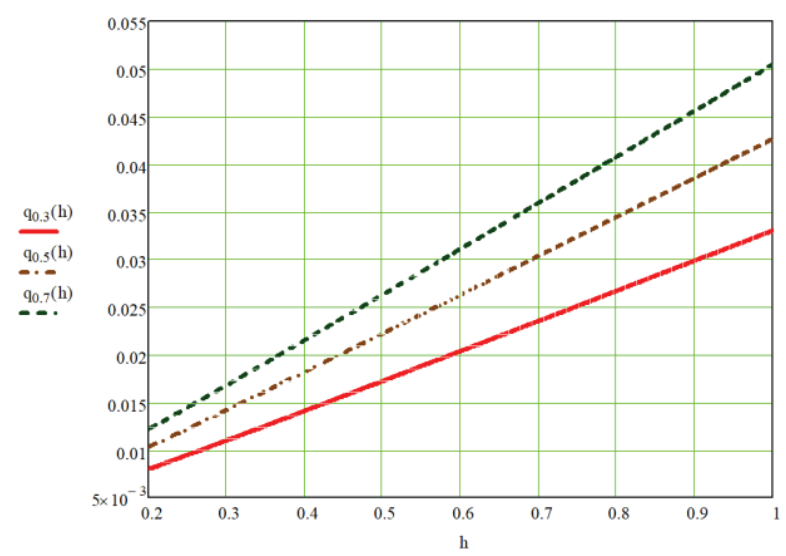

Figure 2. Graphs of dependence of the required height of beam cross-section $h$ and the ultimate load $q$.

Figure 3 presents the dependence of the ultimate crack length in concrete $l_{c r c}$ and design compressive strength of concrete $R_{b}$.

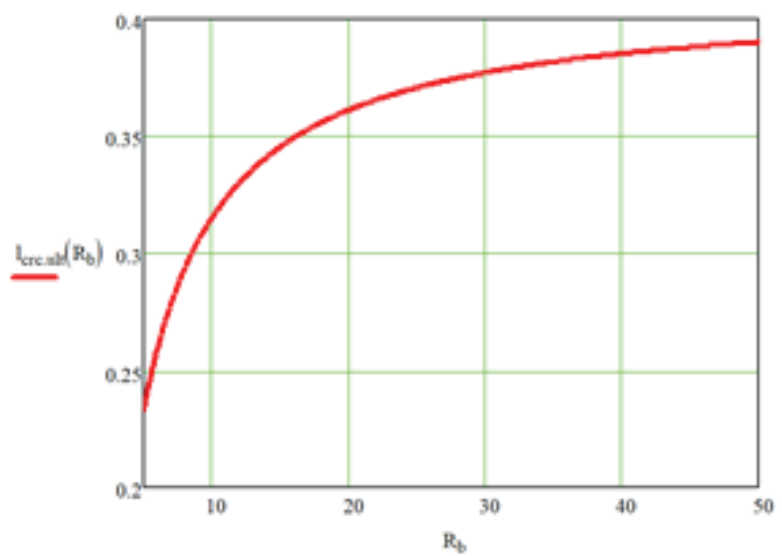

Figure 3. "Ultimate crack length-concrete resistance" diagram.

Figure 3 shows that with a small compressive strength of concrete $(10 \mathrm{MPa})$, the ultimate crack length is $320 \mathrm{~mm}$ or $\sim 0.64 h$ with an increasing of compressive strength, the ultimate crack length increases to the value $\sim 0.74 h$ at 20 $\mathrm{MPa}$ and $\sim 0.76 h$ at $30 \mathrm{MPa}$. The ultimate crack length is stabilized to a value of $\sim 0.78 \mathrm{~h}$ next.

Critical stress intensity coefficient determined by experimental methods for existing reinforced concrete structural elements. These methods are often based on the correlation between critical stress intensity coefficient in concrete and the design compressive strength. Let's consider the problem of estimation the ultimate load $q$ with a given confidence level if critical stress intensity coefficient is random variable with normal distribution. The problem is the simplest problem of the reliability theory [2] with a single random variable, so we present it without additional layouts.

Figure 4 shows the dependence of ultimate load $q$ and $K_{I C}$ variation coefficient $C_{x}$ at the different significance levels. Data is taken from example 1.

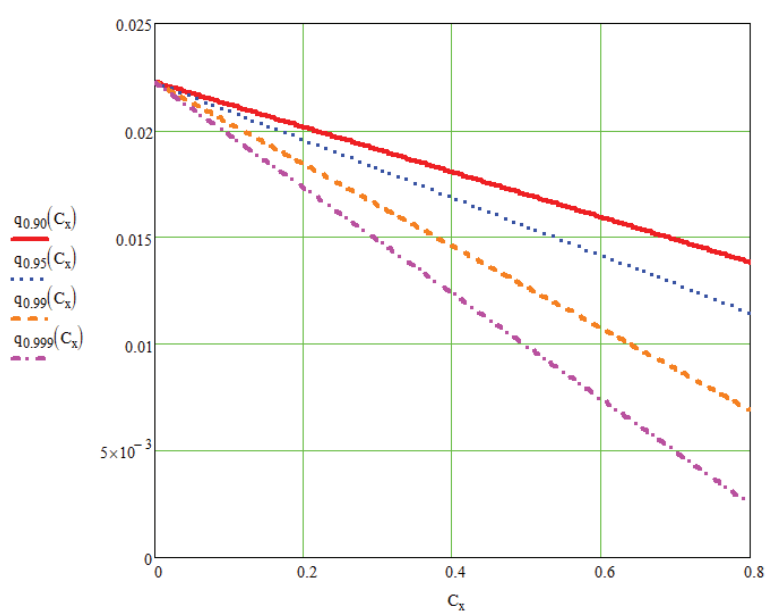

Figure 4. Dependence of ultimate load $q$ and $K_{I C}$ variation coefficient at the different significance levels.

Figure 4 shows that with the increase in the variability of the critical stress intensity coefficient, it is necessary to limit the ultimate load on the RC element to a greater extent in order to ensure the given level of reliability. The inverse problem can also be solved -the reliability analysis of a reinforced concrete beam by the crack length criterion at the operation stage. A limit state mathematical model for reinforced concrete beam can be presented as:

$$
\tilde{q} \leq \sqrt{\frac{l_{c r c, u l t} \cdot\left(\widetilde{K}_{I C}^{b}+K_{I C}^{s}\right)^{2} b^{2} h}{\left(\sqrt{\pi}-\frac{a}{h}-1\right) \cdot\left(\frac{2 \pi-1}{2 \pi}\right)}} \frac{8}{l^{2}},
$$




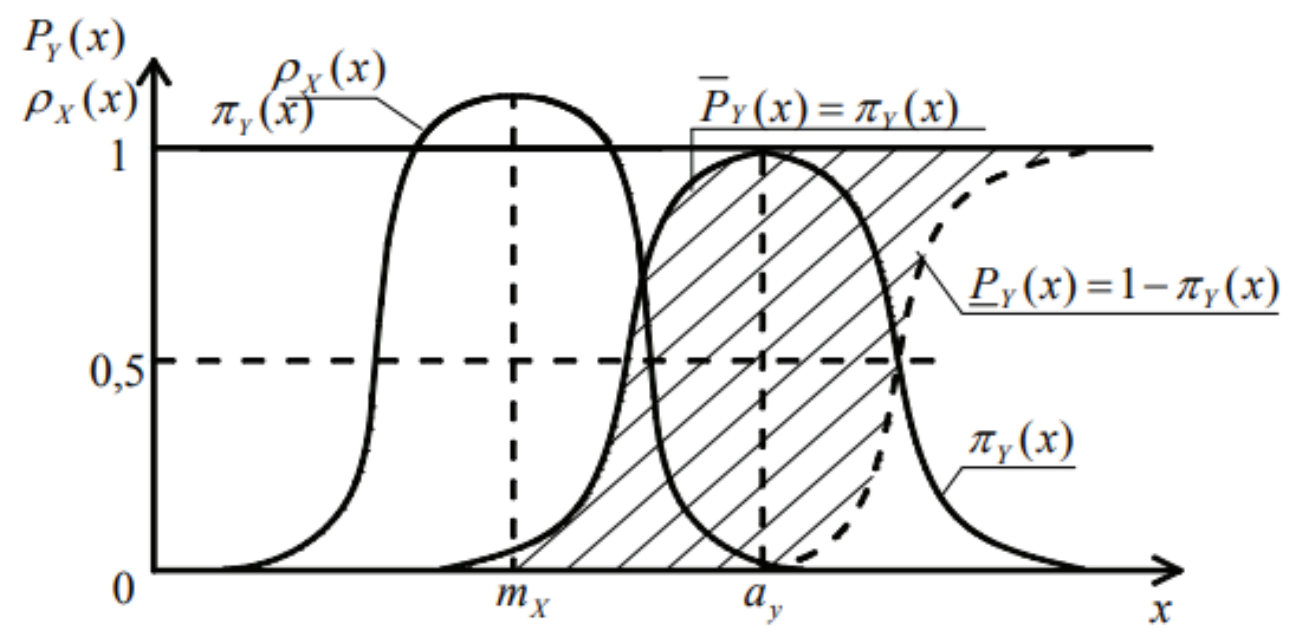

Figure 5. Probability density function of random variable $X$ and distribution function of fuzzy variable Y graphs.

where the wavy line denotes random variables.

Let $\widetilde{q}=X \sqrt{\frac{l_{c r c, u l t} \cdot\left(\widetilde{K}_{I C}^{b}+K_{I C}^{s}\right)^{2} b^{2} h}{\left(\sqrt{\pi}-\frac{a}{h}-1\right) \cdot\left(\frac{2 \pi-1}{2 \pi}\right)}} \frac{8}{l^{2}}=Y$.

Describing the load on the beam $\widetilde{q}$ and the critical stress intensity coefficient $\widetilde{K}_{I C}^{b}$ by the normal distribution, the probability of nonfailure can be found as:

$$
P=\operatorname{Pr}(X \leq Y)=\Phi(\beta)=\Phi\left(\frac{m_{y}-m_{x}}{\sqrt{S_{x}^{2}+S_{y}^{2}}}\right)
$$

where $m_{x}$ and $m_{y}$ - expected values of $X$ and $Y ; S_{x}$ and $S_{y}-$ standard deviations of $X$ and $Y$; $\Phi()$ - value of the Laplace integral function; $\beta$ - reliability index [11-13].

The function parameters are calculated by the follows equations: $m_{x}=m_{q}, S_{x}=S_{q}$,

$$
\begin{gathered}
m_{y}=\sqrt{\frac{l_{c r c, u l t} \cdot\left(m_{K_{I C}^{b}}+K_{I C}^{s}\right)^{2} b^{2} h}{\left(\sqrt{\pi}-\frac{a}{h}-1\right) \cdot\left(\frac{2 \pi-1}{2 \pi}\right)}} \frac{8}{l^{2}}, \\
S_{y}=\sqrt{\frac{l_{c r c, u l t} \cdot\left(S_{K_{I C}^{b}}\right)^{2} b^{2} h}{\left(\sqrt{\pi}-\frac{a}{h}-1\right) \cdot\left(\frac{2 \pi-1}{2 \pi}\right)} \frac{8}{l^{2}}} .
\end{gathered}
$$

If the reliability (probability of non-failure) requirements are not met, the design load value is reduced to the new value $m_{x}=m_{q}$ and the reliability value is recalculated.

However, it is not always possible to get a large amount of statistical data about the parameter $\widetilde{K}_{I C}^{b}$. An approach based on a combination of probability theory and fuzzy set theory can be used in this case. Fuzzy set theory allows to model the variability of a random (fuzzy) variable with a small amount of statistical data. Figure 5 shows the probability density function of random variable $X$ and the distribution function of fuzzy variable $Y$ graphs 
The reliability interval can be calculated using the following equations:

$$
\begin{aligned}
& \underline{P}=1-\int_{0}^{a_{y}} \frac{1}{\sqrt{2 \pi}} \exp \left[-\frac{\left(x-m_{x}\right)^{2}}{2 S_{x}^{2}}\right] \cdot \exp \left[-\left(\frac{x-a_{y}}{b_{y}}\right)^{2}\right] d x- \\
& -\int_{a_{y}}^{\infty} \exp \left[-\frac{\left(x-m_{x}\right)^{2}}{2 S_{x}^{2}}\right] d x ; \\
& \bar{P}=1-\int_{0}^{a_{y}} 0 d x- \\
& -\int_{a_{y}}^{\infty} \exp \left[-\frac{\left(x-m_{x}\right)^{2}}{2 S_{x}^{2}}\right] \cdot\left[1-\exp \left[-\left(\frac{x-a_{y}}{b_{y}}\right)^{2}\right]\right] d x
\end{aligned}
$$

where

$$
a_{y}=\frac{Y_{\max }+Y_{\min }}{2}
$$

- "mean" value;

$$
b_{y}=\frac{Y_{\max }+Y_{\min }}{2 \cdot \sqrt{-\ln \alpha}}
$$

- measure of variability; $\alpha$ - cut (risk) level [14-15]; $Y_{\max }, Y_{\min }-$ minimum and maximum values based on test results and calculations. The reliability is described by the interval $[\underline{P} ; \bar{P}]$.

For the above-described problem:

$$
Y_{\max / \min }=\sqrt{\frac{l_{c r c, u l t} \cdot\left(K_{I C, \max / \min }^{b}+K_{I C}^{s}\right)^{2} b^{2} h}{\left(\sqrt{\pi}-\frac{a}{h}-1\right) \cdot\left(\frac{2 \pi-1}{2 \pi}\right)}} \frac{8}{l^{2}} .
$$

The optimal level of non-failure probability (or reliability index) should be set taking into account the acceptable risk [16-18].

\section{CONCLUSIONS}

1. The article presents probabilistic approach to evaluation the ultimate load on flexural reinforced concrete elements on crack length criterion based of fracture mechanics;

2. The functional relationship between the critical stress intensity coefficient of concrete and the design concrete resistance is given. It can be used in inspections and maintenances of RC elements;

3. An ultimate crack length should be set for reinforced concrete elements individually;

4. The article describes the reliability analysis method for reinforced concrete flexural elements on crack length with limited statistical data.

\section{REFERENCES}

1. Elishakoff I. Probabilistic Methods in the Theory of Structures: Strength of Materials, Random Vibrations, and Random Buckling. World Scientific Publishing Co, 2017, 400 pages.

2. Melchers R.E., Beck A.T. Structural reliability analysis and prediction. John Wiley \& Sons, 2018, 497 pages.

3. Piradov K.A., Savickij N.V. Mekhanika razrusheniya $i$ teoriya zhelezobetona [Fracture mechanics of concrete and reinforced concrete]. // Beton $i$ zhelezobeton, 2014, No. 4, pp. 23-25 (in Russian)

4. Tung N.D., Tue N.V. A fracture mechanics-based approach to modeling the confinement effect in reinforced concrete columns. // Construction and Building Materials, 2016, Volume 102, pp. 893-903.

5. Yehia N.A.B. Fracture mechanics approach for flexural strengthening of reinforced concrete beams. // Engineering Structures, 2009, Volume 31, Issue 2, pp. 404-416.

6. Sau N., Medina-Mendoza J., BorbonAlmada A.C. Peridynamic modelling of 
reinforced concrete structures. // Engineering Failure Analysis, 2019, Volume 103, pp. 266-274.

7. Zajcev Yu.V. Mekhanika razrusheniya dlya stroitelej [Fracture mechanics for structural engineers]. Moscow, Vysshaya shkola, 1991, 287 pages (in Russian)

8. Gvozdev A.A. Novoe v proektirovanii betonnyh i zhelezobetonnyh konstrukcij [New in concrete and reinforced concrete structures design]. Moscow, Strojizdat, 1978, 208 pages (in Russian).

9. Carpinteri A., Carmona J.R., Ventura G. Propagation of flexural and shear cracks through RC beams by the bridged crack model. // Magazine of concrete research, 2007, No. 10, pp. 743-756.

10. Piradov K.A. Teoreticheskie i eksperimental'nye osnovy mekhaniki razrusheniya betona i zhelezobetona [Theoretical and experimental foundations of concrete and reinforced concrete fracture mechanics]. Tbilisi, Energiya, 1998, 355 pages (in Russian)

11. Wang P., Zhang J., Zhai H., Qiu J. A new structural reliability index based on uncertainty theory. // Chinese Journal of Aeronautics, 2017, Volume 30, Issue 4, pp. 1451-1458.

12. Van Coile R., Hopkin D., Bisby L., Caspeele R. The meaning of Beta: background and applicability of the target reliability index for normal conditions to structural fire engineering. // Procedia Engineering, 2017, Volume 210, pp. 528536.

13. Roudak M.A., Shayanfar M.A., Barkhordari M.A., Karamloo M. A new three-phase algorithm for computation of reliability index and its application in structural mechanics. // Mechanics Research Communications, 2017, Volume 85, pp. 53-60

14. Li H., Nie X. Structural reliability analysis with fuzzy random variables using error principle. // Engineering Applications of
Artificial Intelligence, 2018, Volume 67, pp. 91-99.

15. Utkin V.S., Solovyev S.A., Kaberova A.A. Znachenie urovnya sreza (riska) pri raschete nadezhnosti nesushchih elementov vozmozhnostnym metodom [Cut (risk) level in reliability analysis of structural elements by possibilistic methods]. // Stroitel'naya mekhanika $i$ raschet sooruzhenij, 2015, No. 6, pp. 63-67. (in Russian)

16. Trbojevic V. M. Another look at risk and structural reliability criteria. // Structural Safety, 2009, Volume 31, Issue 3, pp. 245250.

17. Zhu B., Frangopol D.M. Reliability, redundancy and risk as performance indicators of structural systems during their life-cycle. // Engineering Structures, 2012, Volume 41, pp. 34-49.

18. Crespo L.G., Kenny S.P., Giesy D.P. Staircase predictor models for reliability and risk analysis. // Structural Safety, 2018, Volume 75, pp. 35-44.

\section{СПИСОК ЛИТЕРАТУРЫ}

1. Elishakoff I. Probabilistic Methods in the Theory of Structures: Strength of Materials, Random Vibrations, and Random Buckling. World Scientific Publishing Co, 2017, 400 pages.

2. Melchers R.E., Beck A.T. Structural reliability analysis and prediction. John Wiley \& Sons, 2018, 497 pages.

3. Пирадов К.А., Савицкий Н.В. Механика разрушения и теория железобетона // Бетон и железобетон, 2014, №4, c. 23-25.

4. Tung N.D., Tue N.V. A fracture mechanics-based approach to modeling the confinement effect in reinforced concrete columns. // Construction and Building Materials, 2016, Volume 102, pp. 893-903.

5. Yehia N.A.B. Fracture mechanics approach for flexural strengthening of reinforced 
concrete beams. // Engineering Structures, 2009, Volume 31, Issue 2, pp. 404-416.

6. Sau N., Medina-Mendoza J., BorbonAlmada A.C. Peridynamic modelling of reinforced concrete structures. // Engineering Failure Analysis, 2019, Volume 103, pp. 266-274.

7. Зайцев Ю.В. Механика разрушения для строителей. - М.: Высшая школа, 1991. $287 \mathrm{c}$.

8. Гвоздев А.А. Новое в проектировании бетонных и железобетонных конструкций. - М.: Стройиздат, 1978. 208 c.

9. Carpinteri A., Carmona J.R., Ventura G. Propagation of flexural and shear cracks through RC beams by the bridged crack model. // Magazine of concrete research, 2007, No. 10, pp. 743-756.

10. Пирадов К.А. Теоретические и экспериментальные основы механики разрушения бетона и железобетона. Тбилиси: Энергия, 1998. - 355 с.

11. Wang P., Zhang J., Zhai H., Qiu J. A new structural reliability index based on uncertainty theory. // Chinese Journal of Aeronautics, 2017, Volume 30, Issue 4, pp. 1451-1458.

12. Van Coile R., Hopkin D., Bisby L., Caspeele R. The meaning of Beta: background and applicability of the target reliability index for normal conditions to structural fire engineering. // Procedia Engineering, 2017, Volume 210, pp. 528536.

13. Roudak M.A., Shayanfar M.A., Barkhordari M.A., Karamloo M. A new three-phase algorithm for computation of reliability index and its application in structural mechanics. // Mechanics Research Communications, 2017, Volume 85, pp. 53-60

14. Li H., Nie X. Structural reliability analysis with fuzzy random variables using error principle. // Engineering Applications of Artificial Intelligence, 2018, Volume 67, pp. 91-99.
15. Уткин В.С., Соловьев С.А., Каберова А.А. Значение уровня среза (риска) при расчете надежности несущих элементов возможностным методом. // Строительная механика и расчет сооружений, 2015, №6, с. 63-67.

16. Trbojevic V. M. Another look at risk and structural reliability criteria. // Structural Safety, 2009, Volume 31, Issue 3, pp. 245250.

17. Zhu B., Frangopol D.M. Reliability, redundancy and risk as performance indicators of structural systems during their life-cycle. // Engineering Structures, 2012, Volume 41, pp. 34-49.

18. Crespo L.G., Kenny S.P., Giesy D.P. Staircase predictor models for reliability and risk analysis. // Structural Safety, 2018, Volume 75, pp. 35-44.

Sergey A. Solovyev, Candidate of Technical Sciences, Associated Professor, Industrial and Civil Department, Vologda State University, 15, Lenin str., Vologda, 160000, Russia.

E-mail: ser6sol@yandex.ru.

Соловьев Сергей Александрович, кандидат технических наук, доцент кафедры «Промышленное и гражданское строительство», Вологодский государственный университет; 160000, Россия, г. Вологда, ул. Ленина, д. 15;

E-mail: ser6sol@yandex.ru. 